\title{
Potential use of lakes as a component of small retention in Wielkopolska
}

\author{
Bogumit Nowak ${ }^{1, *}$, and Mariusz Ptak $^{2}$ \\ ${ }^{1}$ Institute of Meteorology and Water Managament - National Research Institute, Podleśna 61, 01-673 \\ Warszawa, Poland \\ ${ }^{2}$ Department of Hydrology and Water Management, Adam Mickiewicz University, B. Krygowskiego \\ 10, 61-680 Poznań, Poland
}

\begin{abstract}
In the context of the observed climatic changes, unfavourable extreme situations occur increasingly frequently, manifested by, among others, the occurrence of droughts and floods. In the case of Poland, the central part of the country, in administrative terms covering the Wielkopolskie Province, is considered a region with a deficit of water resources. Such a situation was and is determined by a combination of natural and artificial factors. The former ones result from low precipitation and high air temperatures. The latter are the effect of intensive economic development, including large-scale meliorations. Measures mitigating this unfavourable phenomenon are related to the expansion of small retention. Its scale in Wielkopolska is the largest in the country - both in terms of the number of objects and volume of accumulated water. The key component of increasing retention is damming of lakes. According to the presented results, considerable reserves are still available in its scope. With the assumption of increasing water level in lakes by $0.2 \mathrm{~m}$, it could cause an increase in water resources by 31 million $\mathrm{m}^{3}$, and assuming such an increase at a level of 0.5 $\mathrm{m}$, by 78 million $\mathrm{m}^{3}$.
\end{abstract}

\section{Introduction}

The development of civilisation throughout the ages resulted in irreversible transformations of the natural environment. An increase in population, and consequently a higher demand for food and expansion of settlement units, were accompanied by changes, among others, in the land use structure, biosphere, etc. Components of the hydrosphere have been particularly affected by human activity, due to the properties of water and its fast response to any factors influencing its quantity and quality. Water fulfilled various functions (in defence, economy, and recreation), determining the needs for its management. Water was accumulated in situations of deficits or its flow was accelerated in places of its excess. Cases of unfavourable impact of human activity evidently leading to the impoverishment of the hydrosphere are known both in Poland and around the globe [1-3].

\footnotetext{
*Corresponding author: rugosa@op.pl
} 
In the case of Poland, in terms of water resources comparable with semi-desert countries [4], a particularly unfavourable situation occurs in the central part of the country (the area of the Wielkopolskie and Kujawsko-Pomorskie Provinces). According to [5] and authors' research, average long-term specific runoff in the middle course of the Warta and the upper course of the Noteć River does not exceed $2.51 \cdot \mathrm{s}^{-1} \cdot \mathrm{km}^{-2}$. This results from unfavourable climatic conditions (high evaporation, low precipitation), as well as human activity (meliorations and consequently increase in runoff). Kaniecki [6] and Kaniecki and Ptak [7] pointed to a strong transformation of the water network and water relations in the upper and middle course of the Notec River valley resulting from the melioration of wetlands and regulation of its riverbed for navigation purposes. Large-area meliorations were performed practically in the entire area of Wielkopolska [8]. They led to a situation in which the discussed region began struggling with water deficits more and more frequently.

The issue of a decrease in water resources has become so evident that measures were undertaken on the central level to slow down water runoff from the territory of Poland. The launch of the Small Retention Programme was of key importance in this context. Based on the arrangement between the Ministries of Agriculture and Environmental Protection, it came into life in the mid-1990s. Over the first several years of its functioning, the obtained increase in the volume of retained water amounted to 84.7 million $\mathrm{m}^{3}$, mostly due to damming of lakes (39 million $\mathrm{m}^{3}$ ), followed by water accumulation in retention reservoirs [9]. The data show that works for longer water retention particularly focus on natural lakes and artificial reservoirs.

Measures in the scope of Small Retention aim at the elimination of the causes and effects of the deterioration of natural water relations through slowing down the water runoff in the territory of the entire country, minimisation of the effects of droughts, counteracting floods, and reconstruction or preservation of the existing water-wetland areas [http://www.malaretencja.pl]. This involves the use of, among others, artificial water reservoirs, ponds, lakes, or wetlands in which the maximum obtained useful volume does not exceed 5 million $\mathrm{m}^{3}$.

The objective of the paper is to present the state of hydrotechnical infrastructure in the Wielkopolskie Province with particular consideration of lakes, and evaluation of further possibilities of water retention as a result of its damming.

\section{Materials and methods}

The paper employs materials of the Central Statistical Office referring to the quantitative state of objects of implementation of Small Retention, and the Wielkopolska Directorate for Melioration and Water Facilities in Poznań referring to the hydrotechnical infrastructure damming lakes. The data permitted the determination of the scale of hydrotechnical works in Poland with particular consideration of the Wielkopolskie Province. The determination of an increase in retention possible to obtain as a result of damming of lakes was based on data on surface areas of lakes included in the Map of Hydrographic Division of Poland at a scale of 1:10000, and own research conducted in the area of the Gnieźnieńskie Lakeland [10, 11]. For the purpose of calculation of the potential increase in the volume of lakes, the method presented in the paper by Lange [12] was applied, comparing the lake basin to a truncated cone (1). The application of this parameter is a certain simplification, not considering e.g. the microforms of the lake bottom. The methodology, however, is commonly applied, and sufficient for the determination of the volume of water bodies.

$$
V=h / 3\left(P_{0}+2 P_{1}+2 P_{2}+\ldots+2 P_{n-1}+P_{n}+P_{0} P_{1}+P_{1} P_{2}+\ldots+P_{n-1} P_{n}\right)
$$


Where,

$V$ - lake volume $\left[\mathrm{m}^{3}\right]$,

$P_{0,} P_{1}, P_{2} \ldots-$ surfaces between isobaths $\left[\mathrm{m}^{2}\right]$,

$h-\operatorname{depth}[\mathrm{m}]$.

Potential retention capacities of lakes were based on the target water level increase of $0.2 \mathrm{~m}$ for the normal damming level and $0.5 \mathrm{~m}$ for the maximum damming level. The values are within the amplitude of water level fluctuations in flow-through lakes in the annual cycle [13], and simultaneously allow for the stabilisation of the water table, permitting compensation for losses in water resources occurring over the last 50 years [10].

\section{Results and discussion}

Data included in statistical yearbooks Ochrona Środowiska [14], referring to small retention objects in Poland, suggest considerable changes in the scope. At the scale of the entire country, over the last decade, 2586 of new such objects appeared, and the water volume accumulated in them increased by 112.3 million $\mathrm{m}^{3}$ (Fig. 1).

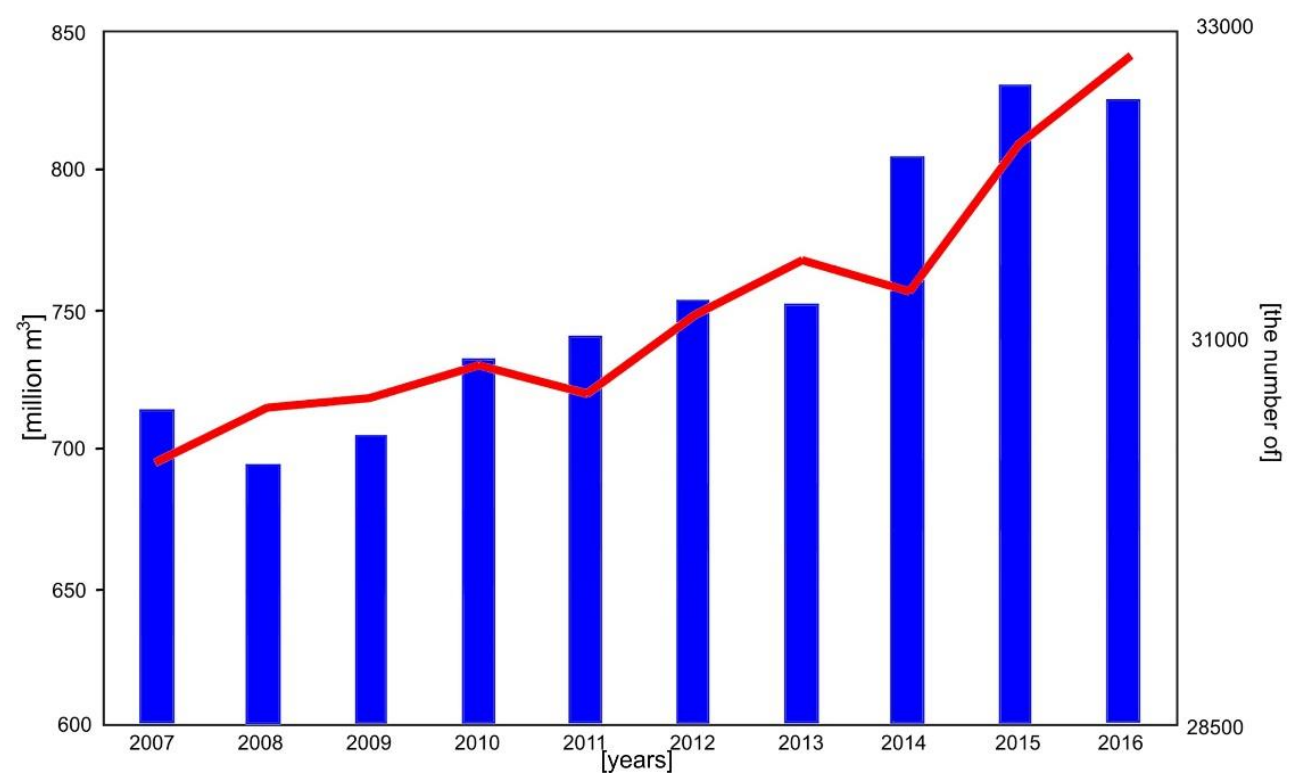

Fig. 1. Changes in the number of small retention objects in Poland (line graph) and water volume (bar graph) in the years 2007-2016 [14].

A measurable benefit from the undertaken actions is an increase in the surface area of irrigated land by 18752.9 ha. According to the aforementioned materials, the highest number of small retention objects concerns the Wielkopolskie Province (Fig. 2). They constitute 21\% of all objects of the type in the country. The number also translates into the highest in Poland volume of retained water, accounting for $23 \%$ of the value for the entire country. Such a state reflects the unfavourable hydrological situation observed in the region. 


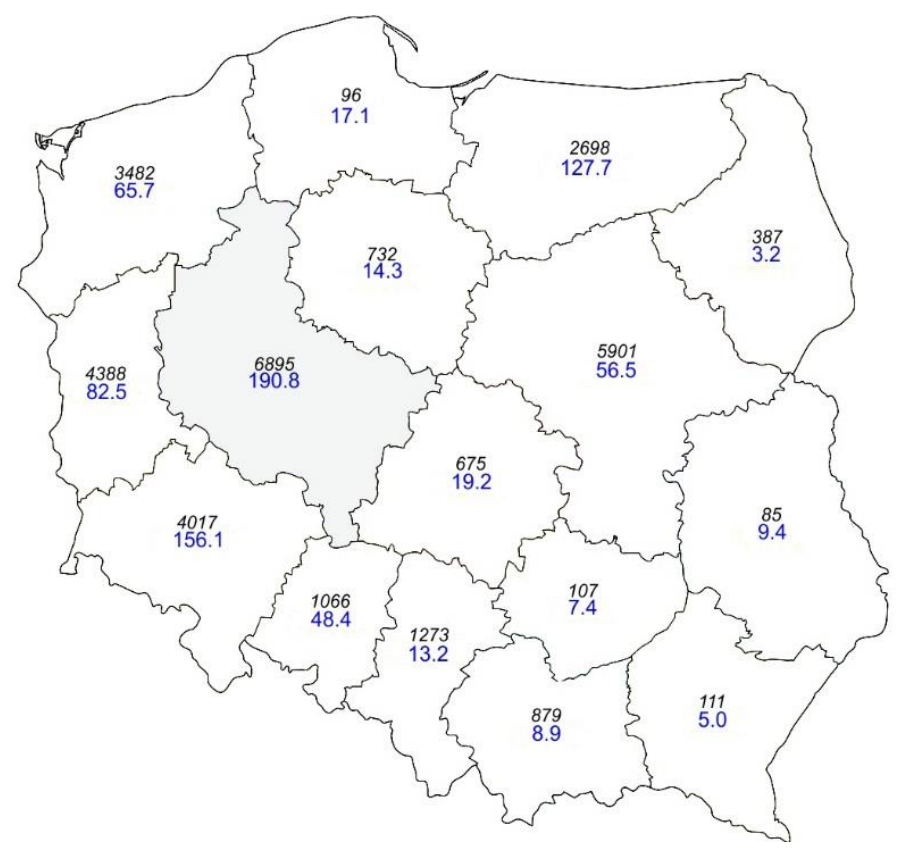

Fig. 2. Number of small retention objects (italic) and their volume in Polish provinces in million $\mathrm{m}^{3}-$ state as at 2016 [14].

In a large portion of the Wielkopolskie Province, lakes are a substantial component of water circulation (Fig. 3). One of their main properties is the ability to retain water. The fact contributes to the mitigation of extreme hydrological phenomena, i.e. rapid floods and occurrence of low flows. It should be emphasised, however, that lakes as concave landforms with positive matter balance (overgrowing, filling with sediments) successively lose their retention capacity [15-18]. Changes in water resources accumulated in lakes overlap with climatic fluctuations, manifested in water level fluctuations $[19,20]$, or direct human interference [21, 1].

According to Sojka et al. [22], damming of lakes is one of the basic directions of building development in catchments containing lakes in terms of meeting the water needs of their users. The importance of a lake in water circulation can be exemplified by southern Wielkopolska (outside the range of the last glaciation), where lack of natural water bodies forced the construction of numerous dam reservoirs, offering benefits not only in environmental, but also in economic terms. 


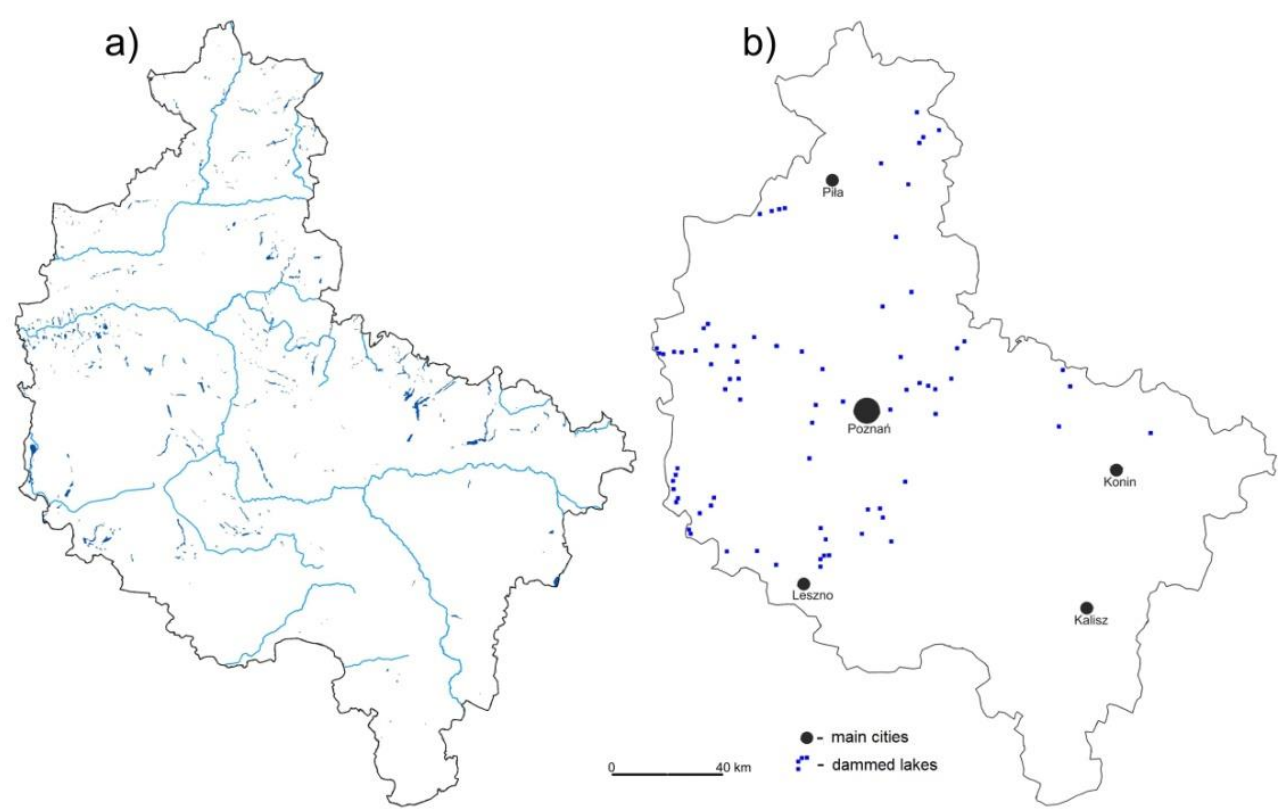

Fig. 3. Hydrography (a) and damming of lakes (b) in Wielkopolska (according to the register of the Wielkopolska Directorate for Melioration and Water Facilities in Poznań as on 13.01.2015).

The role of hydrotechnical facilities in retention of lake waters is well exemplified by the case of Lake Powidzkie. Nowak and Ptak [23] describe a situation in which a weir renovated in 2010, located on the outlet from the lake, together with the occurrence of high precipitation in the period 2010/2011 contributed to the prolongation of occurrence of high water stages, and consequently also to an increase in water resources (Fig. 4).

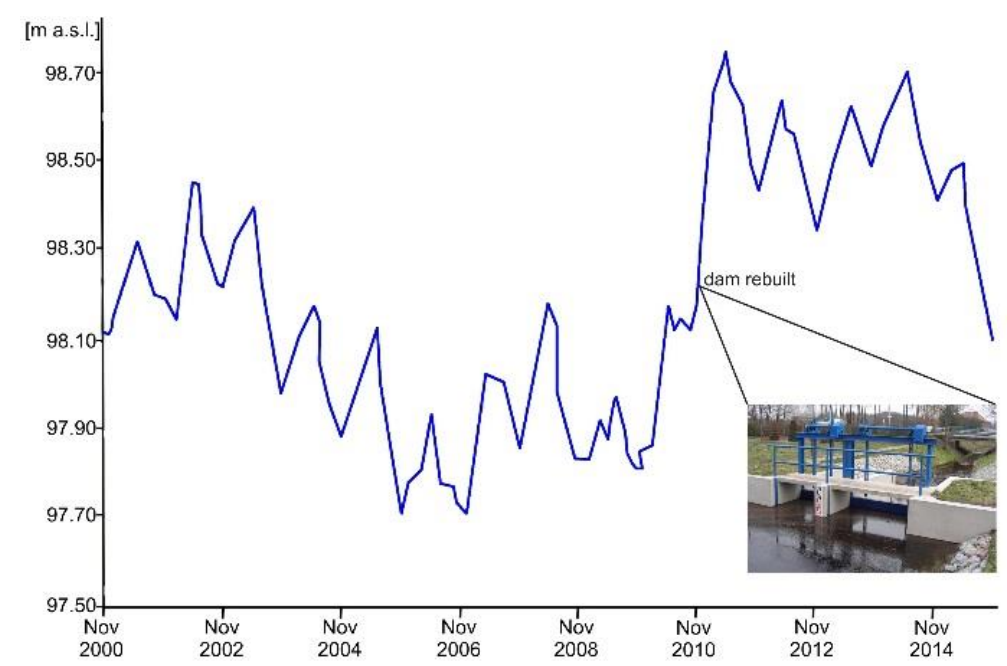

Fig. 4. Course of water levels in Lake Powidzkie before and after the renovation of the weir (following: [23], changed).

According to the Map of Hydrographic Division of Poland at a scale of 1:10000, the area of the Wielkopolskie Province includes 500 lakes with a total surface area of 15000 ha. Based on the adopted methodology, in the case of increasing the water level in the existing lakes through damming by $0.2 \mathrm{~m}$, the obtained increase in water volume, in the scope of retention volume, could amount to 31 million $\mathrm{m}^{3}$. Increasing water level by $0.5 \mathrm{~m}$ could permit 
obtaining an increase in water resources amounting to 78 million $\mathrm{m}^{3}$. The values can be also treated as the flood volume that would increase flood protection in the Oder River catchment. The aforementioned data are estimates. However, they show a high potential in the scope of increase in water resources, and provide the basis for more detailed studies referring to specific cases. Considering measures contributing to an increase in the water resources of the Wielkopolskie Province, documents related to damming of lakes should be evaluated exceptionally positively. Such measures are simpler, cheaper, and less invasive to the environment than the construction of new artificial retention reservoirs leading to large-scale transformations. Damming of lakes, however, should be performed with consideration of potential negative effects of the measure. The basic threat concerning hydrotechnical works conducted on lakes is related to the quality of their waters. Based on the analysis of seven lakes, Gołdyn [24] determined that the main threat related to damming of lakes is the supply of products of matter decomposition from the flooded littoral zone, contributing to an increase in the fertility of the water body. Similar effects, i.e. a decrease in water quality, are mentioned by Burchardt et al. [25] based on the example of Lake Lęgowskie. Nowak and Grześkowiak [16] are of a different opinion. They determined that lakes with higher than average water volume are more resistant to pollutants, providing better conditions for their dissolution. Their observation of degraded lakes suggests that they are usually shallow water bodies with relatively low amounts of water. Interesting results are presented in the paper by Sobczyńska-Wójcik [26], stating that after a quarter of a century of secondary flooding of the area of Lake Nowe Włóki, the ecosystem is stable, and the waters belong to class II/III of cleanliness. Therefore, a change in the character of the environment from land to water did not substantially affect water quality. Other favourable effects of damming of lakes based on the example of Lake Bachotek are provided by Skowron [27]. They include, among others, the stabilisation of water level fluctuations, and the possibility to limit the supply of contaminated transit waters (in the aforementioned case, from the Drwęca River). Another issue are processes developing the shoreline, leading to the erosion of the shore and the supply of terrigenic material to the lake basin. Assuming the maintenance of water levels in a dammed lake not exceeding the multiannual mean water stage, however, such a situation is not expected to substantially determine the remodelling of the shoreline. In a broader context, this is emphasised by, among others, Groblewska [28] who states that an increase in water level within the range of its natural fluctuations inconsiderably contributed to the transformation of the entire ecosystem. Therefore, it seems fully justified to undertake measures aimed at performing at least several years of hydrological observations preceding each decision on lake damming. Moreover, a detailed analysis of historical water levels should be performed. It would provide information on characteristic water stages and their variability in the annual cycle. It is worth emphasising that the performance of hydrotechnical works aimed at damming of lakes to a large degree constitutes the reconstruction of the natural state of the lakes from before large-scale human interference with water conditions. Such cases resulted from direct regulations performed on lakes, and melioration works implemented in their catchments. According to Kaniecki [29], such measures caused a considerable decrease in the water level in lakes: Wolickie $0.5 \mathrm{~m}$, Bronisławskie $0.66 \mathrm{~m}$, Ludzisko $0.61 \mathrm{~m}$. In extreme cases, entire lakes, even those with several hundred hectares of surface area, were subject to the process of drying out [30], which in the context of the analysed issue substantially contributed to the reduction of the water resources of the region in which they occurred.

\section{Conclusion}

Changes in the environment are an irreversible and permanent process. Their effects are of particular importance in modern times, with increasingly frequent occurrence of extreme 
climatic (hurricanes, storms, etc.) and hydrological situations (floods, droughts). Man attempts to influence certain processes to optimise their course in accordance with own needs. Such measures are implemented in reference to the hydrosphere, the resources of which in the territory of Poland, and particularly in Wielkopolska, have gradually decreased throughout the centuries. The need of their restoration has been only recently recognised. Such an approach is confirmed by national and regional programmes, the implementation of which involves considerable expenditures. They include, for example, the Waterenvironmental programme of the country, Draft of water management policy of the country by 2030, Water Management Plan in the Oder River catchment, Small Retention Programme of the Wielkopolskie Province, or the Programme of protection of lakes of North Poland.

The presented data suggest that increasing water retention in lakes is an important component of increasing water resources in the Wielkopolskie Province (recognised as one of regions with the greatest water deficits in Poland). Such an approach is certainly less costly in terms of implementation and further operation than the construction of artificial water reservoirs, and in spite of certain disadvantages, less invasive to the natural environment. It is important that in the majority of cases, hydrotechnical works increasing resources of lakes constitute a kind of their renaturisation to the state from before great melioration works which were particularly intensive in central Poland.

\section{References}

1. M. Ptak, A. Choiński, A. Strzelczak, A. Targosz, Pol J Environ Stud 22, 191 (2013)

2. O. Alizadeh-Choobari, F. Ahmadi-Givi, N. Mirzaei, E. Owlad, Int J Climatol 36, 4276 (2016)

3. Q. Jin, J. Wei, Z.-L. Yang, P. Lin, Remote Sens 9, 900 (2017)

4. P. Kowalczak, R. Farat, M. Kepińska-Kasprzak, M. Kuźnicka, P. Mager, Hierarchia potrzeb obszarowych małej retencji (Materiały badawcze IMGW: Seria: Gospodarka Wodna i Ochrona Wód 19, IMGW, Warszawa, 1997)

5. Atlas hydrologiczny Polski, t. 1 (Wydawnictwa Geologiczne, Warszawa, 1986)

6. A. Kaniecki, Bad. Fizj. A 62, 4 (2011)

7. A. Kaniecki, M. Ptak, Bad. Fizj. A 67, 69 (2016)

8. J. Paluch, Wielkopolskie Spótki Wodne 1842-1918 (Rejonowy Związek Spółek Wodnych, Wągrowiec, 2006)

9. Z. Kowalewski, W. Mioduszewski, C. Bury, Gosp. Wodna 12, 506 (2002)

10. B. Nowak, Rola jezior $w$ drenażu $i$ zasilaniu wód podziemnych na Pojezierzu Gnieźnieńskim $w$ warunkach naturalnych $i$ antropopresji hydrodynamicznej (Praca doktorska, Instytut Geologii Uniwersytet im. Adama Mickewicza w Poznaniu, 2018)

11. B. Nowak (ed.), Sprawozdanie z realizacji tematu badawczego DS.-H 5/2017 pt. Ocena możliwości wykorzystania jezior w ochronie przeciwpowodziowej i odbudowie zasobów wodnych w zlewni górnej i środkowej Noteci (IMGW-PIB, Poznań, 2018)

12. W. Lange, Metody badań fizycznolimnologicznych (Wyd. UG, Gdańsk, 1993)

13. A. Choiński, Limnologia fizyczna Polski (Wyd. Nauk. UAM, Poznań, 2007)

14. Ochrona Środowiska. Rocznik statystyczny (GUS, Warszawa, 2008-2017)

15. A. Choiński, M. Ptak, Pol J Environ Stud 18, 347 (2009)

16. B. Nowak, A. Grześkowiak, Ocena skutków piętrzenia jezior jako element wstępny opracowania modelu rewitalizacji jezior województwa wielkopolskiego, (Zarządzanie zasobami wodnymi w dorzeczu Odry, Wydawnictwo PZITS nr 894, Wrocław, 2010) 
17. A. Choiński, M. Ptak, A. Strzelczak, Oceanol Hydrobiol St 43,178 (2014)

18. A. Choiński, M. Ptak, A. Ławniczak, Pol J Environ Stud 25, 1883 (2016)

19. D. Wrzesiński, M. Ptak, J Geogr Sci 26, 83 (2016)

20. M. Ptak, D. Wrzesiński, A. Choiński, J Hydrol Hydromech 65, 146 (2017)

21. J. Przybyłek, B. Nowak, Biul PIG 445, 513 (2011)

22. M. Sojka, S. Murat-Błażejewska, J. Kanclerz, Infr. i Ekol. Ter. Wiejskich 8, 5 (2010)

23. B. Nowak, M. Ptak, Bull. Geogr. Phys. Geogr. Ser. 14, 2 (2018) (to be published)

24. R. Gołdyn, Zmiany biologicznych i fizyczno-chemicznych cech jakości wody rzecznej pod wplywem jej piętrzenia we wstepnych, nizinnych zbiornikach zaporowych (Wyd. Nauk. UAM, Poznań, 2000)

25. L. Burchardt, A. Kaniecki, H. Pawłat, A. Szymański, Zesz. Nauk. AR we Wrocławiu 246, 39 (1994)

26. K. Sobczyńska-Wójcik, Proceedings of ECOpole 3, 509 (2009)

27. R. Skowron, Limn. Rev. 2, 373 (2002)

28. H. Groblewska H., Gosp. Wodna 9, 372 (2002)

29. A. Kaniecki, Wpływ XIX-wiecznych melioracji na zmiany poziomu wód (Wpływ antropopresji na jeziora: konferencja naukowa, UAM, Poznań, 1997)

30. A. Choiński, M. Ptak, A. Strzelczak, Limn. Rev. 4, 161 (2012) 